\title{
Longevity of seeds and soil seed bank of the Cerrado tree Miconia chartacea (Melastomataceae)
}

\author{
Diego F. Escobar E.* and Victor J. M. Cardoso \\ Departamento de Botânica, Universidade Estadual Paulista (Unesp), Av. 24-A, 1515, Bela Vista, Rio Claro (SP), \\ Brasil
}

(Received 19 January 2015; accepted after revision 12 April 2015; first published online 10 July 2015)

\begin{abstract}
Miconia chartacea is a widely distributed tree in Brazil, occurring at altitudes ranging from $300 \mathrm{~m}$ to $1900 \mathrm{~m}$ in the Caatinga, Cerrado and Atlantic Forest biomes. In this work we attempted to classify $M$. chartacea seeds regarding their behaviour during storage and their germination syndrome and to determine, from a storage test in Cerrado soil and laboratory conditions in situ and ex situ, the longevity of seeds, as well as the capacity of the species to form a soil seed bank. The results suggested that $M$. chartacea seeds form a transient soil seed bank in the Cerrado and can be classified as orthodox in terms of storage behaviour, although the seeds are dispersed with a relatively high water content. The life span of seeds was favoured in soil-stored seeds in comparison with dry storage at $25^{\circ} \mathrm{C}$, whereas storage at low temperatures prevented a decrease of the seed's germinability with storage time (330 d). M. chartacea seeds are dispersed during the dry season and germinate during the next rainy season, which can be classified as an intermediatedry germination syndrome. Seeds of this species are dispersed in the Cerrado when temperatures and soil moisture are relatively low, which favours the formation of a soil seed bank, considering that the seeds tolerate desiccation and their longevity is favoured by low temperatures. A transient seed bank type is favoured by the loss of viability in storage at warm temperatures linked to the rainy season, and the predictable seasonal variations in climate in the region, with germination being restricted to the beginning of the rainy season.
\end{abstract}

Keywords: Brazilian savanna, germinability, germination rate, germination syndrome, seed storage, viability

*Correspondence

Email: barescoesco@gmail.com

\section{Introduction}

The Cerrado is the Brazilian savanna vegetation and it encompasses a core area in Central Brazil and peripheral areas distributed throughout the north of Brazil, extending, north and south, to Bolivia and Paraguay (Ferri, 1977; Ratter et al., 1997). The Cerrado covers around 2 million $\mathrm{km}^{2}$ of Brazil and represents about $23 \%$ of the land surface of this country (OliveiraFilho and Ratter, 2002). The Cerrado varies in form, ranging from dense grassland, generally with a sparse covering of shrubs and small trees (cerrado sensu stricto), to almost closed woodland with a canopy height of 12-15 m (cerradão) (Ratter et al., 1997). The Cerrado is rich in woody species (at least 774), and it has a high level of endemism (43\% of the species). In addition, local diversity (alpha) is low, whereas regional diversity (gamma) is high, with high heterogeneity and species turnover among Cerrado areas (Ratter et al., 1997). More than 55\% of its original vegetation has been modified by human activities (Machado et al., 2004), thus the Cerrado should be considered a priority area for conservation due to its high level of endemism and accelerated habitat loss (Myers et al., 2000).

The Cerrado climate is strongly seasonal, with dry and cool winters from April to September and rainy and warm summers from October to March, with an average precipitation for over $90 \%$ of the area of $800-2000 \mathrm{~mm}$, while average annual temperatures are $18-28^{\circ} \mathrm{C}$ (Ratter et al., 1997). Soils are deep and well drained, acidic, extremely low in available nutrients and with high aluminium content (Franco, 2002). This combination of very dry winters and well-drained soils promotes a water deficit in the topsoil during the dry season (Ratter et al., 1997; Franco, 2002). In Neotropical savannas the establishment and growth of seedlings is heavily constrained by water availability in the soil, limiting germination to the onset of the rainy season (Ray and Brown, 1995; Khurana and Singh, 2001; Franco, 2002; Oliveira, 2008; Silveira et al., 2012). This restriction in germination results in 
selective pressures favouring seed dormancy and soil seed banks in Neotropical savanna species (Salazar et al., 2011).

Garwood (1983) described three germination syndromes in the seasonal moist tropical forest in Panama, where seed germination is synchronized with the onset of the rainy season, allowing seedling growth throughout the growing season. The first, called delayed-rainy syndrome, is characterized by seeds that are dispersed at the end of the rainy season, but will remain dormant in the soil, germinating only during the next rainy season. In the intermediate-dry syndrome, seeds are dispersed in the dry season but will also remain dormant in the soil until the next rainy season. Finally, Garwood (1983) recognized a rapid-rainy syndrome, in which the production of fruits is synchronized with the rainy season, during which seeds are dispersed at the beginning of the rainy season and germinate quickly. Thus, primary dormancy and synchronization of germination with the rainy season are mechanisms that allow seedlings to become established before the onset of seasonal droughts (Garwood, 1983). Oliveira (2008), Silveira et al. (2012) and Salazar et al. (2011) suggested that these three syndromes could occur in the Cerrado, since anemochoric species, which generally disperse late in the dry season, are non-dormant. Furthermore, many zoochorous species that disperse at the beginning of the rainy season are non-dormant (rapid-rainy syndrome), whereas zoochorous species that disperse in the rainy-dry transition period are dormant (delayed-rainy syndrome), and some zoochorous and anemochoric species dispersed during the dry season are dormant (intermediate-dry syndrome).

Both the desiccation effect on seed viability, and storage environment on seed longevity, can account for seed storage behaviour (Hong and Ellis, 1996). According to Hong and Ellis (1996), species whose seeds can be dried to low moisture levels $(2-6 \%$ water content) without losing viability are called orthodox. The life span of orthodox seeds can be extended when they are stored in dry and cold conditions (relative humidity below $30 \%$ and temperatures between -20 and $0^{\circ} \mathrm{C}$ ) (Hong and Ellis, 1996). However, seeds that cannot be dried to water content less than $7-12 \%$, and whose longevity increases when they are stored at $40-50 \%$ relative humidity, can be classified as intermediate. On the other hand, recalcitrant seeds have relatively high (35-90\%) water content when mature and cannot undergo desiccation. Recalcitrant tropical species have seeds with a short life span, typically lasting a few weeks or months (Hong and Ellis, 1996).

Seed storage behaviour is affected by the environmental conditions (temperature and humidity) in which species occur. Thus, orthodox species are generally predominant in environments subject to seasonal or occasional drought, whereas recalcitrant species tend to occur in continually wet environments (Hong and Ellis, 1996)

The soil seed bank is the stock of viable seeds within the soil, and it can be classified as transient or persistent. In the transient bank, no seeds remain viable until the next seed dispersal period; but in a persistent bank, seeds remain viable for at least 1 year after the subsequent dispersal season (Thompson and Grime, 1979). Seed banks are important for the survival of species and plant communities, since they are a source of propagules for recruitment after disturbance, when seed production may be reduced for long periods (Baskin and Baskin, 1998; Dalling and Hubbell, 2002).

Melastomataceae is the fifth most speciose family in the Cerrado (Mendonça et al., 2008), and one of the most important in terms of occurrence (Filgueiras, 2002; Jacobi et al., 2007). The Miconia genus is the most speciose in the family, with 250 species registered in Brazil (Martins et al., 1996). In the Cerrado, Melastomataceae is one of the most abundant and diverse families of the soil seed-bank communities, and forms a persistent soil seed bank (Sassaki et al., 1999). Artificially stored seeds at low temperatures and field-stored seeds of Miconia albicans (Sw.) Steud., M. rubiginosa (Bonpl.) DC (Carreira, 2004), M. theaezans (Bonpl.) Cogn. and M. calvescens DC (Pereira-Diniz and Ranal, 2006) remained viable after 1 year of storage, while warm storage temperatures (25 and $27^{\circ} \mathrm{C}$ ) decreased seed longevity of $M$. albicans and M. rubiginosa (Carreira, 2004). The photoblastic behaviour of Melastomataceae seeds prevents germination of buried seeds, and the light requirement is the physical factor that triggers germination when soil moisture is suitable (Carreira, 2004; Pereira-Diniz and Ranal, 2006; Carreira and Zaidan, 2007). The Miconia species produce a great number of seeds (Dalling et al., 1998; Mendoza and Ramirez, 2006) in a short period of time and enter tropical seed banks (Baskin and Baskin, 1998), hence playing an important role in regeneration following disturbance (Dalling and Hubbell, 2002).

Miconia chartacea Triana (Melastomataceae) is a tree widely distributed in the north-east, mid-west, southeast and south regions of Brazil, occurring at altitudes ranging from 300 to $1900 \mathrm{~m}$ in the Caatinga, Cerrado and Atlantic Forest biomes (Goldenberg, 2010). This species is present in pastures as isolated trees but is also found in late successional ombrophilous forests (GBIF, 2013; speciesLink, 2013). M. chartacea has the highest importance value index for the genus in the study site (Pinheiro, 2006); furthermore, this species is an important resource for frugivorous birds, since it fruits in the dry season (Escobar, 2014), when the abundance of fleshy fruits is low (Oliveira, 2008). However, in spite of its importance and wide distribution, information regarding seed germination and ecophysiology of this species is lacking. 
M. chartacea seeds are dispersed during the dry season (April-September), with a peak of ripe fruits in June, flowering in December and asynchronous fruit ripening. Thus, once released from the mother plant, M. chartacea seeds are exposed to a dry and cool environment before encountering favourable conditions for germination and seedling establishment in the wet season, and this could favour the formation of a soil seed bank. We expected that $M$. chartacea seeds have a transient soil seed bank because this kind of seed bank is more common in perennial species with high annual seed production, dispersed under unfavourable conditions for seedling establishment and in seasonally predictable vegetation (Thompson, 2000; Fenner and Thompson, 2005), considering that fire has been suppressed in the study area since 1962 (Pinheiro, 2006). Otherwise, the strongly seasonal conditions and competition with grasses may result in highly variable seedling recruitment success, favouring persistent soil seed banks in Cerrado woody species (Salazar et al., 2011). Since orthodox seeds tolerate desiccation and low temperatures, we expected to find that $M$. chartacea seeds are orthodox. Therefore, our study aimed to determine the longevity of $M$. chartacea seeds stored both in Cerrado soil and in the laboratory, to evaluate their potential to form a soil seed bank in the Cerrado, and to classify the seeds according to storage behaviour and germination syndrome.

\section{Materials and methods}

\section{Seed collection}

Fruits of M. chartacea were collected from the 'Prof. Dr. Karl Arens' Cerrado reserve in Corumbataí $\left(22^{\circ} 15^{\prime} \mathrm{S}\right.$ and $\left.47^{\circ} 00^{\prime} \mathrm{W}\right)$, São Paulo State, Brazil. This 38.7 ha reserve is composed mainly of cerradão and cerrado sensu stricto to a lesser extent, two Cerrado physiognomies, and fire has been suppressed in the area since 1962 (Pinheiro, 2006). The seeds were collected from several trees in both cerrado sensu stricto and cerradão along a trail running in an east-west orientation within the reserve; the seeds were mixed. The climate is humid tropical with a dry and cool period from April to September, and a rainy and warm period extending from October to March (Fig. 1). The average annual temperature and rainfall recorded from 1941 to 1970 in Corumbataí were $22^{\circ} \mathrm{C}$ and $1342 \mathrm{~mm}$, respectively (Pinheiro, 2006).

\section{Seed mass}

Fresh mass of seeds was determined for 272, 227 and 203 recently harvested seeds collected in April 2012,
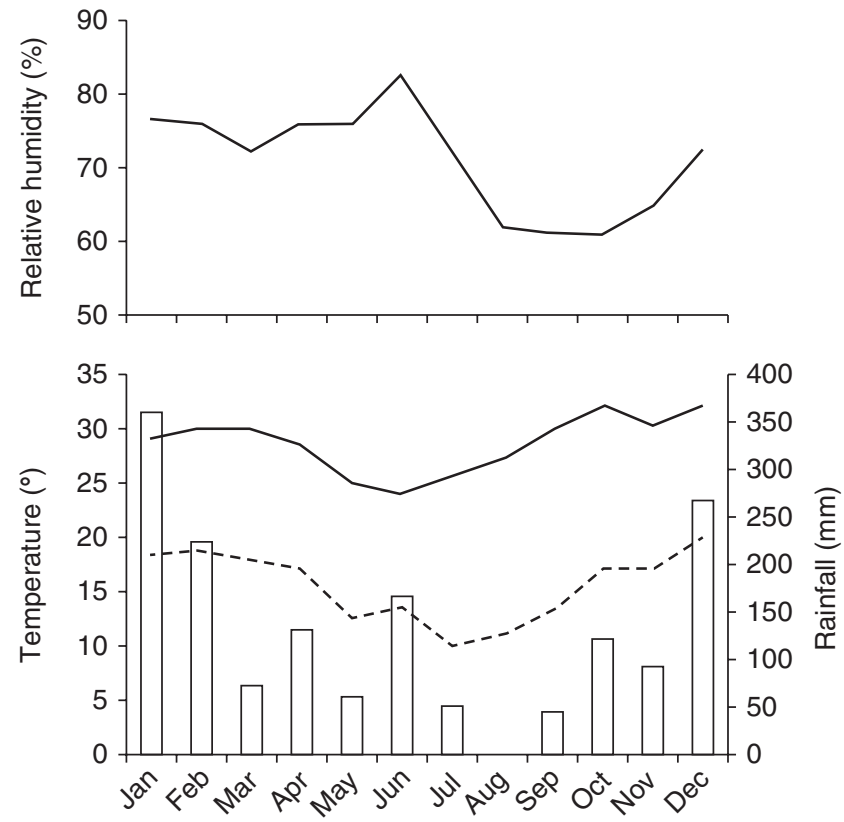

Figure 1. Climatological data for Corumbataí region, 20122013. All data are from CEAPLA/IGCE/UNESP; rainfall (bars), maximum temperature (solid line), minimum temperature (dotted line).

June 2012 and April 2013, respectively. Seeds were weighed individually with an analytical balance (Ohaus, Pioneer PA214; Ohaus, New Jersey, USA).

\section{In situ and ex situ seed longevity}

In situ and ex situ seed longevity was determined for seeds stored in field and laboratory conditions, respectively. We performed two assays, both with a factorial design $(4 \times 8)$ with four storage conditions two field conditions (open and closed sites), two laboratory conditions $\left(7^{\circ} \mathrm{C}\right.$ and $\left.25^{\circ} \mathrm{C}\right)-$ as well as eight storage periods. Assay I was carried out with seeds collected on 8 May 2012 and stored for $27 \mathrm{~d}$ in paper bags at $25^{\circ} \mathrm{C}$, and Assay II was performed with seeds harvested on 6 June 2012 and stored for $6 \mathrm{~d}$ in paper bags at $25^{\circ} \mathrm{C}$. Two assays were carried out in order to assess possible storage and seed collection time effects on seed viability. Since results from both assays exhibited similar tendencies, only data from Assay II are shown.

In situ longevity was estimated by placing the seeds in nylon mesh bags of $c .15 \times 5 \mathrm{~cm}$ and $1-\mathrm{mm}$ mesh size ( 25 seeds per bag), which were then laid on the soil surface and covered with a layer of leaf litter from the area. The bags were placed at two sites (open and closed), chosen according to the height and canopy opening (Table 1). Irradiance at soil level was taken with a LI-COR LI-1000 radiometer (LI-COR, Nebraska, USA) utilizing a linear sensor. The irradiance $(I)$ in the 'open' and 'closed' sites was calculated according to the 
Table 1. Relative irradiances (\%) recorded during the dry (June 2012), rainy (November 2012) and transition from dry to rainy seasons (September 2012) at open and closed Cerrado areas at 'Prof. Dr. Karl Arens' Reserve

\begin{tabular}{llll} 
& \multicolumn{3}{c}{ Recording dates } \\
\cline { 2 - 4 } Site & June 2012 & Sept. 2012 & Nov. 2012 \\
\hline Open & $3.51 \pm 0.57^{* *}$ & $10.26 \pm 1.65^{* *}$ & $41.05 \pm 2.5^{* *}$ \\
Closed & $1.98 \pm 0.59^{* *}$ & $2.08 \pm 0.46^{* *}$ & $11.97 \pm 4.24^{* *}$ \\
\hline
\end{tabular}

**Statistical difference between sites (Student's $t$-test, $P<0.01$ ).

formula: $I=\left(I_{\mathrm{i}} / I_{\mathrm{s}}\right) \times 100$, where $I_{\mathrm{i}}$ is the percentage of irradiance at point $\mathrm{i}$, and $I_{\mathrm{S}}$ is the direct sunlight irradiance. For each site type (open and closed) eight bags were placed at four locations (replicates) distributed along the borders of a trail running in an east-west orientation within the reserve; these locations were located in a cerradão area and $30-100 \mathrm{~m}$ from each other along the trail mentioned above. At 43, 76, 106, 135, 218, 268,300 and $330 \mathrm{~d}$, a bag was removed from each point and all the seeds were mixed to one sample. These seeds were tested for germination in Petri dishes containing filter paper saturated with distilled water and kept at $25^{\circ} \mathrm{C}$ under continuous white light $\left[\simeq 34.4 \mu \mathrm{mol} \mathrm{s}^{-1} \mathrm{~m}^{-2}\right.$ photosynthetically active radiation (PAR)]. Seed viability analyses were carried out on non-germinated seeds by means of the tetrazolium test $\left(1 \%\right.$ solution for $24 \mathrm{~h}$ at $30^{\circ} \mathrm{C}$; Silveira et al., 2012).

To estimate ex situ longevity, paper bags were filled with 25 seeds each and stored in tightly capped jars (four bags per jar) at $7^{\circ} \mathrm{C}$ (refrigerator) and $25^{\circ} \mathrm{C}$ (climate-controlled room). The lowest air temperatures during seed dispersal time for $M$. chartacea are around $7^{\circ} \mathrm{C}$, while $25^{\circ} \mathrm{C}$ is the average temperature of the growing season [Centro de Análise e Planejamento Ambiental, Instituto de Geociências e Ciências Exatas, UNESP (CEAPLA/IGCE/UNESP) climatic data for 2012-2013]. For germination tests, seeds were placed in Petri dishes containing filter paper saturated with distilled water, and incubated at $25^{\circ} \mathrm{C}$ under continuous white light $\left(\simeq 34.4 \mu \mathrm{mol} \mathrm{s}{ }^{-1} \mathrm{~m}^{-2}\right.$ PAR). Seeds stored for 0 (initial time), 43, 76, 106, 135, 218, 268, 300 and $330 \mathrm{~d}$ were used. Seed viability analyses were carried out as described above.

\section{Soil seed bank}

Soil samples were collected in two different periods: on 3 October 2012, at the end of the fruiting of $M$. chartacea and beginning of the rainy season, and on 13 March 2013, at the end of the rainy season and before the ripening of $M$. chartacea fruits. At each time point, two soil samples (each $30 \mathrm{~cm} \times 30 \mathrm{~cm} \times 2 \mathrm{~cm}$; litter removed) were collected from each of 20 sampling points located $30 \mathrm{~m}$ from each other along the trail mentioned above; sampling points were different from the eight points used for in situ longevity assays. Samples were collected on both sides of the trail at a distance of $1 \mathrm{~m}$ from the edge. The number of intact seeds per sample was determined by sieving (3-mm mesh size) the soil and removing the seeds. The viability of seeds was assessed by germination assays on filter paper at $15 / 25^{\circ} \mathrm{C}$ under continuous white light $\left(\simeq 34.4 \mu \mathrm{mol} \mathrm{s}^{-1} \mathrm{~m}^{-2} \mathrm{PAR}\right)$ and validated by the tetrazolium test. When possible, 30 seeds per sample were tested, but that depended on the number of available seeds in each sample. Priority was given to germination tests over tetrazolium tests, thus eight of the 40 samples had fewer than 30 intact seeds, and in 12 of the samples the tetrazolium test was not carried out due to insufficient seeds.

\section{Desiccation and storage temperature}

The influence of artificial drying and $e x$ situ storage conditions on germination was tested with seeds collected on 15 May 2013. Once the moisture content (MC) from recently harvested seeds was determined using the gravimetric method on a fresh weight basis (Silva, 1988), seeds were placed in a desiccator containing silica gel at room temperature until the desired MC was reached. Seeds were then removed and tested for germination. Assays were carried out with seeds containing the following MCs: $37.2 \%$ (recently harvested), 8.5\%, 7.5\%, 6.5\%, 4.9\% and $3.7 \%$. To test if the seeds had orthodox behaviour, additional germination assays were carried out on seeds with a MC of 4.9 and $6.5 \%$ after storage of $93 \mathrm{~d}$ at $7^{\circ} \mathrm{C}$ (refrigerator) and $-18^{\circ} \mathrm{C}$ (freezer). For storage, desiccated seeds were put in paper bags (five bags with 30 seeds each) within a tightly capped glass bottle placed inside another airtight container. Germination tests were performed in Petri dishes (five dishes per treatment with 30 seeds each), on filter paper kept saturated with distilled water at $20^{\circ} \mathrm{C}$ under continuous white light ( $\left.\simeq 34.4 \mu \mathrm{mol} \mathrm{s}^{-1} \mathrm{~m}^{-2} \mathrm{PAR}\right)$.

\section{Data analysis}

The criterion adopted for germination was the protrusion of the primary root followed by geotropic curvature. The germination was recorded periodically up to approximately $90 \mathrm{~d}$ after sowing, when germination curves tended to stabilize. The germinability $(G)$ was calculated from the formula $G=\{[(n / N)$ $\times 100] / v\} \times 100$, where $n=$ number of germinated seeds, $N=$ total number of seeds; and $v=$ maximum percentage of viable seeds, considering all samples. The average germination rate $(V \mathrm{~m})$ was determined according to Labouriau (1983): $V \mathrm{~m}=\Sigma n_{\mathrm{i}} / \Sigma n_{\mathrm{i}} \cdot t_{\mathrm{i}}$, where $n_{\mathrm{i}}$ is the number of germinated seeds during the 
time interval $t_{\mathrm{i}}$. Results were analysed by descriptive statistical analysis, where the respective confidence intervals $(\alpha=0.05)$ were determined when necessary. The variation of germinability and germination rate as a function of time and in situ and ex situ storage was analysed by two-way analysis of variance (ANOVA). The number of viable seeds in the soil sample in two periods was compared with Mann-Whitney nonparametric analyses. Percentage and germination rate of seeds with different MC, as well as amongst dry seeds ( 6.5 and $4.9 \% \mathrm{MC}$ ) stored at low temperatures and fresh or dry not stored seeds were compared using one-way ANOVA, whereas possible interactions amongst $\mathrm{MC}$ and storage temperatures were tested by two-way ANOVA.

\section{Results}

\section{Seed mass}

The average fresh mass of seeds was $15 \pm 5 \mathrm{mg}$, $15 \pm 6 \mathrm{mg}$ and $18 \pm 5 \mathrm{mg}$ for the seeds collected in April 2012, June 2012 and April 2013, respectively. Weighted average fresh weight $(n=702$ seeds) was $16 \pm 5 \mathrm{mg}$ and the mode was $15 \mathrm{mg}$.

\section{In situ and ex situ longevity}

All initially field-stored seeds were present throughout the sampling period, and no germinated seeds were found in the nylon bags. Germinability varied with time (two-way ANOVA, $F=67, P<0.01$ ), storage conditions (two-way ANOVA, $F=22, P<0.01$ ) and interaction (two-way ANOVA, $F=8, P<0.01$ ) between these factors (Fig. 2). The germinabilities of open and closed field-stored seeds were similar to each other (Tukey, $P=0.39$ ), they remained constant until 4-5 months and then decreased, reaching zero after storage for $218 \mathrm{~d}$ (Fig. 2A). Moreover, seeds stored at $7^{\circ} \mathrm{C}$ differed in germinability from those of field-stored seeds and seeds stored at $25^{\circ} \mathrm{C}$ (Tukey, $P<0.001$ ), and they maintained or increased germinability in comparison to those that were not stored (initial time). On the other hand, seeds stored at $25^{\circ} \mathrm{C}$ differed in germinability from those of field-stored seeds and seeds stored at $7^{\circ} \mathrm{C}$, and showed a steady decline, reaching zero after $76 \mathrm{~d}$ of storage (Tukey, $P<0.001$ ). Although the values for germination rate (Fig. 2B) presented higher variation, the results were similar to those described for germinability.

\section{Soil seed bank}

The number of intact seeds extracted per soil sample was similar in the samples from October 2012 and
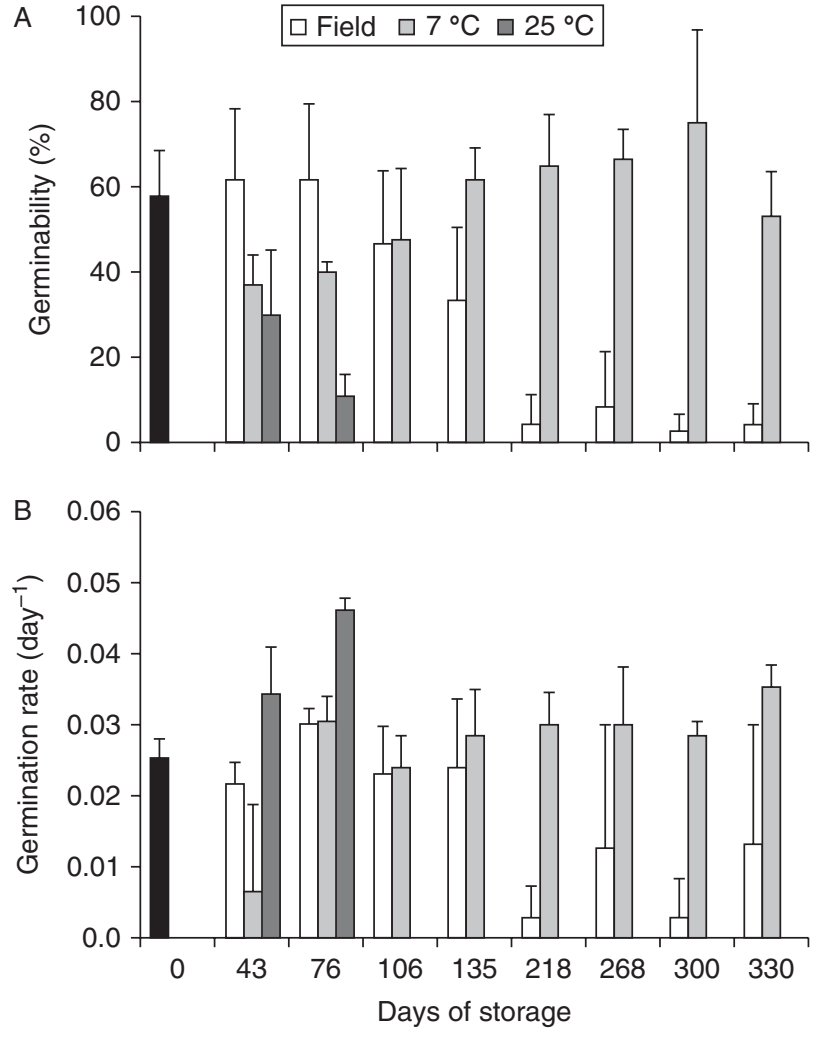

Figure 2. Germinability (A) and average germination rate (B) of Miconia chartacea seeds stored for different periods (days) in Cerrado soil (field, empty bars) and in the laboratory at $7^{\circ} \mathrm{C}$ (light grey bars) and $25^{\circ} \mathrm{C}$ (dark grey bars). Data from Assay II, started on 12 June 2012 with seeds harvested on 6 June 2012. The germination assay was carried out for $90 \mathrm{~d}$ under white light at $25^{\circ} \mathrm{C}$. Vertical lines are confidence intervals $(\alpha=0.05)$. Black bars are the respective values for recently harvested seeds (initial time).

March 2013 (Mann-Whitney, $P=0.7$ ), $720 \pm 860$ seeds $\mathrm{m}^{-2}$ and $693 \pm 645$ seeds $\mathrm{m}^{-2}$, respectively. However, the number of viable seeds $\mathrm{m}^{-2}$ in the soil was significantly higher (Mann-Whitney, $P<0.001$ ) in the samples from October 2012, shortly after the fruit maturation stage was finished, than in samples from March 2013, shortly before the next fruit maturation period (204.5 \pm 238.6 and $8.4 \pm 20.96$ viable seeds $\mathrm{m}^{-2}$, respectively). For soil samples collected in October 2012 (beginning of the rainy season), 18 of the 20 samples had viable seeds, whereas for soil samples collected in March 2013 (end of the rainy season) only 7 of the 20 samples contained viable seeds. Seed viability varied greatly among the sampled points, with a coefficient of variation $(\mathrm{CV})$ of $54 \%$ and $157 \%$ for the October samples and March samples, respectively.

\section{Desiccation and storage temperature}

Recently harvested seeds had a mean MC of $37.2 \%$, and germinability was not affected by drying the seed 
to a MC of $3.7 \%$ (Tukey confidence interval, $\alpha=0.05$, Fig. 3A), although it did favour the germination rate (ANOVA, $F=4.7, P=0.004$, Fig. 3B). The germinability of non-stored seeds submitted to desiccation tended to increase coupled with an increase in seed MC, where seeds dried to $8.5 \%$ germinated at a higher percentage than recently harvested seeds (Tukey confidence interval, $\alpha=0.05$, Fig. 3A). The average germination rate $(V \mathrm{~m})$ of artificially dried seeds tended to decrease slightly ( $F$-test linear regression, $P<0.035)$ with increasing seed MC, and dried seeds had higher $V \mathrm{~m}$ compared to recently harvested ones (Tukey confidence interval, $\alpha=0.05$, Fig. 3B).

Germinability of seeds dried to 6.5 and $4.9 \% \mathrm{MC}$ stored for $93 \mathrm{~d}$ at 7 or $-18^{\circ} \mathrm{C}$ did not differ either from recently harvested seeds or dry seeds not stored (ANOVA, $F=1.74, P=0.198$ and $F=0.31, P=0.816$, seeds dried to 6.5 and $4.9 \%$, respectively, Fig. 3A). However, cold storage $\left(7\right.$ and $-18^{\circ} \mathrm{C}$ ) adversely affected the germination rate compared with nonstored seeds with similar MC (ANOVA, $F=13.8$, $P<0.001$ and $F=8.82, P=0.001$, seeds dried to 6.5
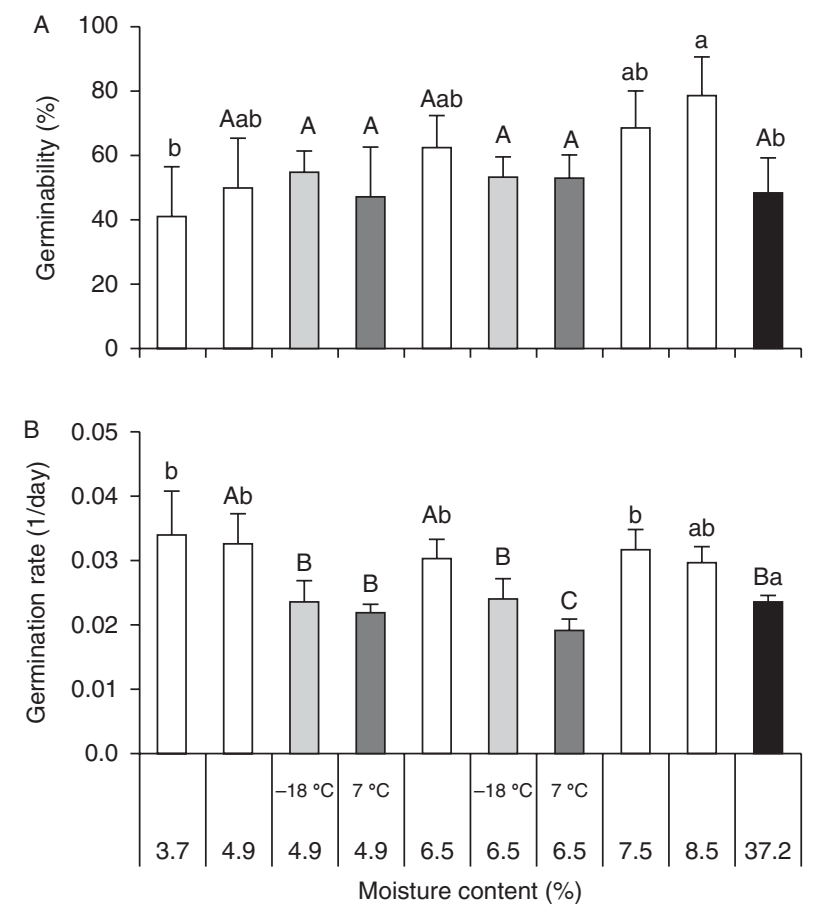

Figure 3. Germinability (A) and germination rate (B) of Miconia chartacea seeds artificially dried to different initial moisture contents (MC). Germination assays were carried out for $85 \mathrm{~d}$ under white light at $25^{\circ} \mathrm{C}$ with dried seeds that were not stored (empty bars) and dried seeds stored for $93 \mathrm{~d}$ at $-18^{\circ} \mathrm{C}$ (light grey bars) and $7^{\circ} \mathrm{C}$ (dark grey bars). Black bars show data from recently harvested seeds. Vertical lines are the confidence intervals $(\alpha=0.05)$. Different lower-case letters indicate statistical differences in the seed $\mathrm{MC}$ (one-way ANOVA, Tukey, $\alpha=0.05$ ). Upper-case letters indicate differences in the seed $\mathrm{MC}$ and storage temperature (two-way ANOVA, Tukey, $\alpha=0.05$ ). and $4.9 \%$, respectively, Fig. 3B), but did not affect the germination rate compared to that of freshly harvested seeds (Tukey confidence interval, $\alpha=0.05$ ). Storage temperature (two-way ANOVA, $F=0.16, P=0.691$ ), MC $(F=0.66, P=0.430)$ and the interaction of these factors $(F=0.66, P=0.430)$ did not affect germination percentage, while germination rate was highest in seeds stored at $-18^{\circ} \mathrm{C}$ (two-way ANOVA, $F=7.31$, $P=0.016)$, regardless of $\mathrm{MC}(F=1.71, P=0.209)$ and interaction between $\mathrm{MC}$ and storage temperature $(F=2.14, P=0.163)$ (Fig. 3B).

\section{Discussion}

The longevity of $M$. chartacea seeds depends on storage conditions, with seeds stored in the field retaining their initial viability for about 5 months and then decreasing, while the viability of seeds dry-stored at $25^{\circ} \mathrm{C}$ decreased from the beginning of storage. On the other hand, dry storage at $7^{\circ} \mathrm{C}$ clearly favoured viability, which was maintained after 10 months of storage. A similar response to dry storage was reported for the Cerrado trees $M$. albicans and M. rubiginosa (Carreira, 2004), in which seed viability was maintained for 22 months by storage at $4^{\circ} \mathrm{C}$, decreasing at warm temperature $\left(25^{\circ} \mathrm{C}\right)$. However, the life span of field-stored $M$. albicans and $M$. rubiginosa seeds was higher (20 months) than that of $M$. chartacea, suggesting that those species can form persistent soil seed banks (Carreira, 2004).

According to Hong and Ellis (1996), the optimum ex situ storage conditions are associated with the lowest air temperatures occurring where populations of the species occur, which during the seed dispersal season for this species in the Cerrado study site fluctuated around $7.6 \pm 3.1^{\circ} \mathrm{C}$ (CEAPLA/IGCE/UNESP climatic data for 2012-2013). Thus, M. chartacea seeds can be conserved ex situ in germplasm banks when stored dry at low temperatures $\left(7^{\circ} \mathrm{C}\right)$. The effect of storage at low temperature in maintaining the seed viability has been reported for the Cerrado species M. albicans, M. rubiginosa (Carreira, 2004), M. theaezans, M. calvescens (Pereira-Diniz and Ranal, 2006), Tibouchina pulchra Cogn., T. granulosa Cogn. (Zaia and Takaki 1998), Huberia semiserrata DC (Brischi, 2000), Tabebuia heterophylla (A.P. Candolle) Britton (Silva et al. 2001) and Porophyllum lanceolatum DC (Cesarino, 2002). However, in comparison with soil storage, seed viability of $M$. chartacea is not preserved during dry storage at $25^{\circ} \mathrm{C}$, as reported for Psychotria vellosiana Benth., P. hoffmansegiana (Schult.) Müll. Arg. (Araujo and Cardoso, 2006, 2007), Bidens gardneri Baker (Sassaki et al. 1999), M. albicans and M. rubiginosa (Carreira, 2004) in the Cerrado.

Considering that the longevity of buried seeds in the field was approximately 5 months, M. chartacea 
seeds that are dispersed from May to June, for example, could retain their ability to germinate until at least the beginning of the rainy season (OctoberMarch). Thus, $M$. chartacea seeds would not be viable long enough to form a persistent soil seed bank in Cerrado, but rather they form a transient bank in which viable seeds persist in the soil for less than 1 year (Bewley et al., 2013). The lack of persistence of M. chartacea seeds in the soil is due to a decline of seed viability rather than germination in the field, since no recently germinated seedlings were recorded in fieldstored assays; moreover, these seeds are photoblastic at constant and alternating temperatures and afterripening did not alter this behaviour (Escobar, 2014). The temperature rise during the rainy season can explain the decline in viability in the field-stored seeds, because storage at warm temperature $\left(25^{\circ} \mathrm{C}\right)$ decreased the seed viability.

The number of viable $M$. chartacea seeds retrieved from Cerrado soil samples decreased from $204 \pm 64$ seeds $\mathrm{m}^{-2}$ at the end of the fruiting period (October 2012) to $8 \pm 5$ seeds $m^{-2}$ at the end of the rainy season (March 2013), strongly supporting the conclusion that seeds form a transient seed bank and that seedling recruitment largely depends on recently dispersed seeds, unlike M. albicans, M. rubiginosa, $M$. theaezans and M. calvescens, which form permanent soil seed banks in the Cerrado (Carreira, 2004; Pereira-Diniz and Ranal, 2006). This discrepancy may be due to differences in regenerative requirements, since $M$. chartacea is a nonpioneer species whose spatial distribution does not depend on the formation of forest gaps (Higuchi et al., 2011), while M. albicans, M. rubiginosa, M. theaezans and $M$. calvescens are pioneer species that depend on unpredictable gap formations for seedling establishment (Carreira, 2004; Pereira-Diniz and Ranal, 2006). On the other hand, field-stored seeds of woody species in Cerrado tend to germinate or lose their viability in less than 1 year (Sassaki et al., 1999; Cesarino, 2002; Paulino, 2002; Salazar et al., 2011), thus transient soil seed banks are common in Cerrado woody species, as well as low recruitment of woody species from a persistent seed bank (Salazar et al., 2011). Therefore, $M$. chartacea seeds would fit the general pattern observed for woody Cerrado species, in which the timing of seed dispersal and dormancy, rather than a persistent seed bank, seems to control both seedling recruitment and germination time (Salazar et al., 2011).

The storage test showed that $M$. chartacea seeds remain viable even when dried to $3.7 \%$ MC (fresh weight basis) and both their germinability and germination rate increased when they were dried to $8.5 \%$ MC. A germination-promoting effect of desiccation has been reported for mature seeds from several species, including dormant seeds of tree species in which cold stratification requirements can be replaced partially by desiccation (Thomsen, 1997). M. chartacea seeds not only tolerate desiccation, but their germination was not affected if seeds were dehydrated to $6.5 \%$ and $4.9 \% \mathrm{MC}$ and stored at low temperatures $\left(7^{\circ} \mathrm{C}\right.$ and $-18^{\circ} \mathrm{C}$ ). Therefore, considering that $M$. chartacea seeds tolerate relatively low MC levels $(\simeq 5 \%)$ and have their longevity extended when they are dry stored at low temperatures, the species can be classified as having orthodox seed storage behaviour (Bewley et al., 2013). Orthodox seed storage behaviour is most common in environments subject to seasonal drought (Hong and Ellis, 1996) such as Cerrado, a biome in which orthodox behaviour predominates and is associated with the low relative humidity and drought of the dry season (Ribeiro, 2010). This storage behaviour would allow $M$. chartacea seeds to form a transient soil seed bank, since newly dispersed seeds would be exposed to a dry and cold period before encountering favourable conditions for germination and seedling establishment in the wet season.

$M$. chartacea seeds extracted from mature fruits (in the stage of abscission) have relatively high MC $(37-40 \%)$, suggesting that these seeds do not undergo maturation drying and are dispersed with a moisture level characteristic of recalcitrant seeds (Castro et al., 2004). Thus, under natural conditions it is likely that $M$. chartacea seeds withstand a marked post-dispersal dehydration that is not only tolerated by the seeds but may also favour seed germination when soil water potentials increase during the rainy season, since the drying can increase seed sensitivity to gibberellin, reduce the time to completion of germination and partially replace cold stratification (Thomsen, 1997). Considering the germination syndromes established by Garwood (1983), M. chartacea seeds have a 'dryintermediate' type of germination syndrome, being dispersed during periods of relatively little or no rain and remaining dormant and/or quiescent in the soil until the rainy season.

In the Cerrado, $M$. chartacea seeds are dispersed when temperature and soil moisture are relatively low, thus their desiccation tolerance, the effect of low temperatures in preserving seed viability and their photoblastic behaviour (Escobar, 2014) favour the development and maintenance of a soil seed bank. A transient soil seed bank is favoured considering the relatively high annual seed production typical of Miconia species, the loss of viability under storage at warm temperatures linked to the rainy season, and the predictable seasonal variations in climate in the region, with germination being restricted to the beginning of the rainy season.

\section{Acknowledgements}

The authors thank CEAPLA/IGCE/UNESP for the climatic data. 


\section{Financial support}

The authors thank Conselho Nacional de Desenvolvimento Científico e Tecnológico (CNPq) and Coordenação de Aperfeiçoamento de Pessoal de Nível Superior (CAPES) for financial support.

\section{Conflicts of interest}

None.

\section{References}

Araujo, C.G. and Cardoso, V.J.M. (2006) Storage in Cerrado soil and germination of Psychotria vellosiana (RUBIACEAE) seeds. Brazilian Journal of Biology 66, 709-717.

Araujo, C.G. and Cardoso, V.J.M. (2007) Psychotria hoffmansegiana (Willd ex Roem. and Schult.) Mull. Arg. and Palicourea marcagravii St. Hil. (Rubiaceae): potential for forming soil seed banks in a Brazilian Cerrado. Brazilian Journal of Biology 67, 421-427.

Baskin, C.C. and Baskin, J.M. (1998) Seeds. Ecology, biogeography, and evolution of dormancy and germination. San Diego, Academic Press.

Bewley, J.D., Bradford, K., Hilhorst, H.W.M. and Nonogaki, H. (2013) Seeds: Physiology of development, germination and dormancy (3rd edition). New York, Springer.

Brischi, A.M. (2000) Efeito da luz e da temperatura na germinação de sementes de Huberia semiserrata DC. (Melastomataceae). Master's thesis, Universidade Estadual Paulista, Rio Claro, São Paulo, Brazil

Carreira, R.C. (2004) Germinação de sementes de Miconia albicans (Sw.) Triana e M. rubiginosa (Bonpl.) DC., Melastomataceae, do cerrado de Mogi Guaçu, SP. PhD thesis, Instituto de Botânica da Secretaria do Meio Ambiente, São Paulo, Brazil.

Carreira, R.C. and Zaidan, L.B.P. (2007) Germinação de sementes de espécies de Melastomataceae de Cerrado sob condições controladas de luz e temperatura. Hoehnea 34, 261-269.

Castro, R.D., Bradford, K.J. and Hilhorst, H.W.M. (2004) Desenvolvimento de sementes e conteúdo de água. pp. 149-162 in Ferreira, A.G.; Borghetti, F. (Eds) Germinação: do Básico ao Aplicado. Porto Alegre, ArtMed.

Cesarino, F. (2002) Bancos de sementes do solo da Reserva Biológica e Estação Experimental de Moji-Guaçu, em área de cerrado no Estado de São Paulo. PhD thesis, Universidade Estadual de Campinas, Campinas, SP, Brazil

Dalling, J.W. and Hubbell, P. (2002) Seed size, growth rate and gap microsite conditions as determinants of recruitment success for pioneer species. Journal of Ecology 90, 557-568.

Dalling, J.W., Hubbell, S.P. and Silvera, K. (1998) Seed dispersal, seedling establishment and gap partitioning among tropical pioneer trees. Journal of Ecology 86, 674-689.

Escobar, D.F. (2014) Fisioecologia de sementes de Miconia chartacea (Melastomataceae) ocorrente em uma reserva de cerrado, no município de Corumbataí (SP). MSc thesis, Universidade Estadual Paulista, Rio Claro, Brazil.

Fenner, M. and Thompson, K. (2005) The ecology of seeds. Cambridge, Cambridge University Press.
Ferri M.G. (1977) Ecologia dos Cerrados. pp. 15-36 in IV Simposio Sobre o Cerrado, São Paulo, Brazil.

Filgueiras, T.S. (2002) Herbaceous plant communities. pp. 121-139 in Oliveira, P.S.; Marquis, R.J. (Eds) The Cerrados of Brazil: Ecology and natural history of a Neotropical savanna. Washington, DC, Columbia University Press.

Franco, A.C. (2002) Ecophysiology of woody plants. pp. 178-197 in Oliveira, P.S.; Marquis, R.J. (Eds) The Cerrados of Brazil: Ecology and natural history of a Neotropical savanna. Washington, DC, Columbia University Press.

Garwood, N.C. (1983) Seed germination in a seasonal tropical forest in Panama: a community study. Ecological Monographs 53, 159-181.

GBIF (Global biodiversity information facility). (2013) Copenhagen. Available at http://www.gbif.org/ (accessed 23 July 2013).

Goldenberg R. (2010) Miconia chartacea in Lista de Espécies da Flora do Brasil, Jardim Botânico do Rio de Janeiro. Available at http://floradobrasil.jbrj.gov.br/2010/ FB009684 (accessed 20 July 2012)

Higuchi, P., Silva, A.C., van den Berg, E. and Pifano, D.S. (2011) Associações espaciais entre indivíduos de diferentes espécies de Miconia spp. RUIZ \& PAV. (Melastomataceae). Revista Árvore 35, 381-389.

Hong, T.D. and Ellis, R.H. (1996) A protocol to determine seed storage behavior. Technical Bulletin no. 1. Italy, International Plant Genetic Resources Institute.

Jacobi, C.M., Carmo, F.F., Vincent, R.C. and Stehmann, J.R. (2007) Plant communities on ironstone outcrops: a diverse and endangered Brazilian ecosystem. Biodiversity Conservation 16, 2185-2200.

Khurana, E. and Singh, J.S. (2001) Ecology of seed and seedling growth for conservation and restoration of tropical dry forest: a review. Environmental Conservation $28,39-52$.

Labouriau, L.G. (1983) A Germinação das Sementes. Washington, DC, Secretaria Geral da Organização dos Estados Americanos.

Machado, R.B., Ramos, N.M.B., Pereira, P.G.P., Caldas, E.F., Gonçalves, D.A., Santos, N.S., Tabor, K. and Steininger, M. (2004) Estimativas de perda de área do Cerrado brasileiro. Brasília, DF, Conservation International.

Mendonça, R.C., Felfili, J.M., Walter, B.M.T., Silva, M.C. Jr, Rezende, A.V., Filgueiras, T.S., Nogueira, P.E. and Fagg, C.W. (2008) Flora vascular do bioma Cerrado: checklist com 12.356 espécies. pp. 421-1279 in Sano, S.M.; Almeida, S.P.; Ribeiro, J.F. (Eds) Cerrado: Ecologia e flora. Brasília, Embrapa Cerrados.

Mendoza, H. and Ramírez, B. (2006) Guía ilustrada de géneros Melastomataceae y Memecylaceae de Colombia. Bogotá, Instituto de Investigación de Recursos Biológicos Alexander von Humboldt, Univerisad del Cauca.

Myers, N., Mittermeier, R.A., Mittermeier, C.G., Fonseca, G.A.B. and Kent, J. (2000) Biodiversity hotspots for conservation priorities. Nature 403, 853-858.

Oliveira, P.E. (2008) Fenologia e biologia reprodutiva das espécies de cerrado. pp. 169-192 in Sano, S.M.; Almeida, S.P. (Eds) Cerrado: Ambiente e flora. Planaltina, EMBRAPACPAC.

Oliveira-Filho, A.T. and Ratter, J.A. (2002) Vegetation physiognomies and woody flora of the cerrado biome. pp. 91-120 in Oliveira, P.S.; Marquis, R.J. (Eds) The Cerrados of Brazil: Ecology and natural history of 
a Neotropical savanna. Washington, DC, Columbia University Press.

Paulino, E.C.B. (2002) Estabelecimento dos indivíduos de Copaifera langsdorffii Desf. sob diferentes intensidades luminosas em uma área de mata nativa e ecofisiologia de sementes considerando o efeito do soterramento e de submersão em água. Master's thesis, Universidade Guarulhos, São Paulo, Brazil.

Pereira-Diniz, S.G. and Ranal, M.A. (2006) Germinable soil seed bank of a gallery forest in Brazilian Cerrado. Plant Ecology 183, 337-348.

Pinheiro, M.H.O. (2006) Composição e estrutura de uma comunidade savânica em gradiente topográfico no município de Corumbataí (SP, Brasil). PhD thesis, Universidade Estadual Paulista, Rio Claro, Brazil.

Ratter, J.A., Ribeiro, J.F. and Bridgewater, S. (1997) The Brazilian Cerrado vegetation and threats to its biodiversity. Annals of Botany 80, 223-230.

Ray, G.J. and Brown, B.J. (1995) Restoring Caribbean dry forests: evaluation of tree propagation techniques. Restoration Ecology 3, 86-94.

Ribeiro, L.C. (2010) Aspectos ecofisiológicos da germinação de sementes de espécies de cerrado sensu stricto e da mata de galeria da biota Cerrado expostas a diferentes condições de estresse. MSc thesis, Universidade de Brasília, Brasilía, Brazil

Salazar, A., Goldstein, G., Franco, A.C. and MirallesWilhelm, F. (2011) Timing of seed dispersal and dormancy, rather than persistence in soil seed-banks, control recruitment of woody plants in Neotropical savannas. Seed Science Research 21, 103-116.

Sassaki, R.M., Rondon, J.N., Zaidan, L.B.P. and Felippe, G.M. (1999) Number of buried seeds and seedlings emergence in cerradao, cerrado and gallery forest soils at
Pedregulho, Itirapina (SP), Brazil. Revista Brasileira de Botânica 22, 147-152.

Silva, A., Figliolia, M.B., Aguiar, I.B. and Perecin, D. (2001) Liofilização e armazenamento de sementes de ipê-rosa Tabebuia heterophylla (A.P. Cabdolle) Britton (Bignoniaceae). Revista Brasileira de Sementes 23, 252-259.

Silva, E.M.N. (1988) Determinação da umidade. pp. 60-69 in Pina-Rodrigues, F.C.M. (Coord.) Manual de Análise de Sementes. Campinas, Fundação Cargil.

Silveira, F.A.O., Ribeiro, R.C., Oliveira, D.M.T., Fernandes, G.W. and Lemos-Filho, J.P. (2012) Evolution of physiological dormancy multiple times in Melastomataceae from Neotropical montane vegetation. Seed Science Research 22, 37-44.

speciesLink. (2013) Available at http://splink.cria.org.br/ index?criaLANG =pt (accessed 23 July 2013).

Thomsen, K.A. (1997) The effects of harvest time and drying on dormancy and storability in beechnuts. pp. 45-52 in Ellis, R.H.; Black, M.; Murdoch, A.J.; Hong, T.D. (Eds) Basic and applied aspects of seed biology. Current plant science and biotechnology in agriculture, Vol. 30. Dordrecht, Kluwer Academic Publishers.

Thompson, K. (2000) The functional ecology of soil seed banks. pp. 215-236 in Fenner, M. (Ed.) Seeds: The ecology of regeneration in plant communities (2nd edition). Wallingford, CABI.

Thompson, K. and Grime, J.P. (1979) Seasonal variation in the seed banks of herbaceous species in ten contrasting habitats. Journal of Ecology 67, 893-921.

Zaia, J.E. and Takaki, M. (1998) Estudo da germinação de sementes de espécies arbóreas pioneiras: Tibouchina pulchra Cogn. e Tibouchina granulosa Cogn. (Melastomataceae). Acta Botanica Brasilica 12, 221-229. 